\title{
JOSEPH CONRAD: THREE NOVELS
}




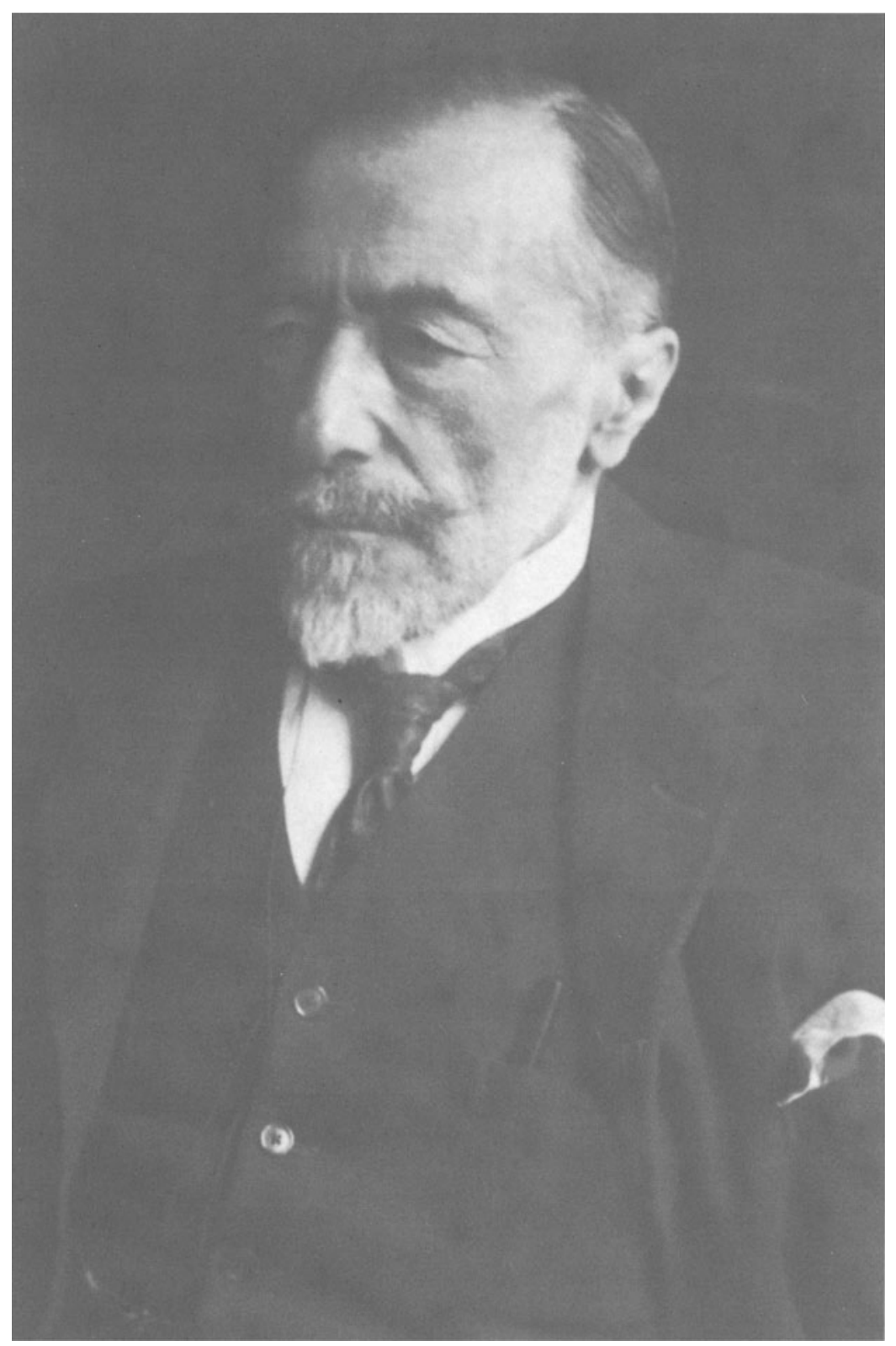

Joseph Conrad in 1923, aged about 65

(Estate of John Conrad/photo T. and R. Annan and Sons) 


\title{
JOSEPH CONRAD: THREE NOVELS
}

\section{Heart of Darkness The Secret Agent The Shadow-Line}

\author{
Joseph Conrad
}

Edited with an introduction and notes by NORMAN PAGE

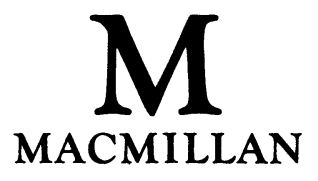


Introduction, notes, glossary and chronology ( Norman Page 1995

All rights reserved. No reproduction, copy or transmission of this publication may be made without written permission.

No paragraph of this publication may be reproduced, copied or transmitted save with written permission or in accordance with the provisions of the Copyright, Designs and Patents Act 1988, or under the terms of any licence permitting limited copying issued by the Copyright Licensing Agency, 90 Tottenham Court Road, London W1P 9HE.

Any person who does any unauthorized act in relation to this publication may be liable to criminal prosecution and civil claims for damages.

First published 1995 by

THE MACMILLAN PRESS LTD

Houndmills, Basingstoke, Hampshire RG21 2XS and London

Companies and representatives throughout the world

ISBN 978-0-333-61096-1

ISBN 978-1-349-23831-6 (eBook)

DOI 10.1007/978-1-349-23831-6

A catalogue record for this book is available from the British Library

Typeset by EXPO Holdings, Malaysia 


\section{Contents}

A Note on the Text vi

Introduction $\quad$ ix

Heart of Darkness

The Secret Agent 93

$\begin{array}{ll}\text { The Shadow-Line } & 339\end{array}$

$\begin{array}{ll}\text { Notes } & 446\end{array}$

Glossary of Nautical Terms $\quad 451$

A Conrad Chronology 453 


\section{A Note on the Text}

Heart of Darkness was begun in mid-December 1898 and finished within about a month. It was serialized in three instalments in the monthly Blackwood's Magazine (FebruaryApril 1899), but Conrad discouraged his friends from reading the serial version, urging them to wait until they had access to the complete story. It was included, together with two other stories that had appeared in Blackwood's, in Youth: A Narrative and Two Other Stories, published by Blackwood's in November 1902. The volume contains a dedication 'To my wife'. The text in the present edition is based on that in the volume titled Youth, Heart of Darkness, The End of the Tether (1946), forming part of the Collected Edition of Conrad's writings published by J. M. Dent, which is in turn based on the Uniform Edition of 1923-8.

The Secret Agent originated as a short story titled 'Verloc' one of numerous occasions when Conrad's original conception was on a far smaller scale than the eventual work - and thirteen pages of it were sent to his literary agent, J. B. Pinker, on 21 February 1906. It grew rapidly during the ensuing months, and a version of the novel was finished by November of that year and was serialized in a New York magazine, Ridgway's: A Militant Weekly for God and Country, between 6 October 1906 and 12 January 1907. Conrad was, however, dissatisfied with this version - he told one friend that he 'must not take it too seriously' (12 September 1906), another that it had 'no social or philosophical intention' (7 November 1906) - and between mid-May and mid-July 1907 he wrote, by his own account, another 28-30,000 words. This revised and expanded version was published by Methuen (London) and Harper \& Brothers (New York) in September 1907. The present text is based on the Dent Collected Edition (1947).

Conrad began work on The Shadow-Line early in 1915 and had completed it by the end of the year, the final page of the manuscript bearing the date 15 December 1915. (The statement in the Author's Note, added in 1920, that 'This book 
was written in the last three months of the year 1916' appears to be one more example of Conrad's confusion over dates.) It was serialized in the English Review, a distinguished journal of which Conrad had been one of the founders, in seven instalments from September 1916 to March 1917, appearing also in the Metropolitan Magazine (New York) in October 1916, and was issued in volume form by J. M. Dent in March 1917. The present text is substantially based on the Dent Collected Edition (1945), with a few variants adopted from the 1921 Heinemann edition, which had the benefit of Conrad's corrections. Two misprints from the Dent text pointed out by Jeremy Hawthorn in his admirable edition of The Shadow-Line (Oxford University Press, 1985) have also been corrected. I am greatly indebted to Professor Hawthorn's work on the text of this novel.

A few obvious misprints in the copy-texts have been silently corrected, but the temptation to tidy up Conrad's often unidiomatic English has been resisted. At many points what is conceivably a slip of the pen or a printer's error perpetuated in subsequent editions may very possibly be no more than Conrad's own eccentric usage, and the careful reader of his work will often be reminded that he was writing in his third language. To cite just one example among many: nearly all editions of The Secret Agent contain the phrase 'like the eyes of convinced man' (p. 271 of this edition), where normal usage seems to demand 'like the eyes of a convinced man'. The editors of the Cambridge Edition of the novel (1990) adopt the emendation 'a convinced man', though neither the manuscript nor the serial version has the article.

I am grateful to Professor J. H. Stape for advice on Conrad's text. 


\section{Introduction}

The three works included in this volume belong to three different stages of Conrad's career. Heart of Darkness, one of the masterpieces of modern symbolism, is strictly speaking a Victorian text, having been written, in a matter of a few weeks, between mid-December 1898 and 6 February 1899; its first appearance before the public was as a three-part serial in Blackwood's Magazine (the long-established and highly regarded "Maga") in February to April 1899, and Conrad later included it in the volume Youth: A Narrative and Two Other Stories, published in 1902. Coming between Nostromo and Under Western Eyes, The Secret Agent belongs to Conrad's greatest creative period. A version of it was begun while he and his family were on holiday in France in the spring of 1906, and was completed by early November of the same year. It was serialized in an American magazine from 6 October 1906 to 12 January 1907, but Conrad was far from satisfied with this version and set to work to revise and expand it in the early summer of 1907, this revised version appearing in volume form in September. The Shadow-Line, arguably his last masterpiece, was begun early in 1915 and finished by the end of the year. Serialized in the English Review (September 1916-March 1917), it was issued as a slim volume in March 1917.

Historically, the period of some eighteen years between the composition of Heart of Darkness and the publication of The Shadow-Line takes us from the last years of Victoria's reign to the Great War: in personal terms, the time-span covered begins with Conrad, who had made a late start at authorship, still struggling to make a living and a reputation, and ends with him as a man of nearly sixty enjoying a long-delayed popularity and commercial success, and - though he was to live for another seven years - near the end of his period of significant creative activity as a writer of fiction.

Much, perhaps most, of that fiction is deeply, though not necessarily straightforwardly, autobiographical, and discussion of two of the three texts in this volume can hardly proceed without detailed reference to Conrad's life. At the outset 
of his career as a writer - his second career, following (or slightly overlapping with) his first career as a merchant seaman - he had found himself handicapped by the lack of that basic knowledge that is indispensable for the novelist: knowledge of social manners and customs, of family relationships, even of the material circumstances of everyday life in English society. This ignorance was the result partly of his being a Pole who had lived in France and for whom English itself was only his third language, but it was compounded by the fact that he had spent most of his adult life at sea. As he told his literary mentor Edward Garnett, "I have spent half my life knocking about in ships, only getting ashore between voyages. I know nothing, nothing! except from the outside. I have to guess at everything!"

The alternative to guessing at everything was to write a different kind of story, one that did not attempt to portray the everyday life of English society - in other words the sociological novel of realism that had been the dominant mode of the nineteenth century. Hence he turned to the material that lay readily to hand, the real-life stories that belonged to his own seafaring and exotic experience or that of others he had encountered or heard about. Taking this direction, he might easily have become an imitator, and perhaps a successful one, of writers such as Robert Louis Stevenson and Henry Rider Haggard, who had already practised this kind of alternative fiction.

Conrad's mind, however, was essentially philosophical and speculative, and his transformation of basically simple yarns into metaphysical dramas produced something very different from Stevenson or Haggard, and something that was capable of puzzling his first readers. One reviewer of The Nigger of the "Narcissus" (1897), his first substantial masterpiece, observed that the story offered "no plot and no petticoats", and, in a year that also saw the publication of novels by such authors as Hardy, Gissing and Henry James, the puzzlement is understandable.

The origins of Heart of Darkness go back a number of years in Conrad's experience. But first it is important to note that to speak of Conrad's fiction as "autobiographical" is to employ a kind of shorthand that may be seriously misleading. Like many people who are not great writers, Conrad was an un- 
reliable guide to his own past, the unreliability springing from a habit of reshaping his personal history that may have been partly conscious, partly unconscious. Specifically, he tended to mythologize his experience and impose on his past life an order and sense of purpose and direction that it never had. As a result, his fictions usually present an approximation (often a very close approximation) to rather than a record of actual experience, in so far as the latter can be conclusively ascertained.

In Heart of Darkness private and public history intersect, but the private history is modified and the public history made deliberately non-specific. Although, for instance, Conrad has in mind real places such as Brussels and the Congo, neither is actually.named in the text, and in referring to them simply as a "city" and a "river" he seems to be moving away from the kind of specificity (or illusion of specificity) that is one of the hallmarks of mainstream nineteenth-century fiction.

As for the relationship of Marlow's African experiences to those of the historical Józef Korzeniowski, the Anglicized Joseph Conrad concedes in the Author's Note (written for the story's republication in 1917) that liberties have been taken with the facts. Drawing attention to the difference between the title-story of the volume and Heart of Darkness, he writes:

"Youth" is a feat of memory. It is a record of experience; but that experience, in its facts, in its inwardness and in its outward colouring, begins and ends in myself. "Heart of Darkness" is experience too; but it is experience pushed a little (and only very little) beyond the actual facts of the case for the perfectly legitimate, I believe, purpose of bringing it home to the minds and bosoms of the readers. There it was no longer a matter of sincere colouring. It was like another art altogether. That sombre theme had to be given a sinister resonance, a tonality of its own, a sombre vibration that, I hoped, would hang in the air and dwell on the ear after the last note had been struck.

The resonance that hangs in the air is surely Kurtz's dying cry, "The horror! the horror!", and, although the figure of Kurtz may well have a real-life prototype, much of the climax of the story in which he is the central figure is the product of invention - and that despite Conrad's ironic insistence that "The sustained invention of a really telling lie demands a 
talent which I do not possess". The revealing word here, of course, is "sustained", and the sentence that precedes the one I have just quoted from his autobiographical book $A$ Personal Record (1912) states of Heart of Darkness: "As for the story itself it is true enough in its essentials." The reader is left to decide where the "essentials" end and the non-essentials begin.

Those essentials, Conrad's creative starting-point, constituted a crucial phase of his own past, and the relevant biographical facts are clear enough. At the beginning of 1888, in circumstances that will be referred to more fully in a later section of this Introduction, he had assumed command of the Otago and had accumulated experiences that were to be put to literary use nearly thirty years later in The Shadow-Line. In March 1889, however, he resigned his command, and for the rest of that year found himself professionally at something of a loose end. (It was, by his own account, the year in which he "sat down to write", thus inaugurating his second profession.) In November he travelled to Brussels, where he had family contacts, to be interviewed (like Marlow) for the command of a Congo steamboat, but it was several months before the appointment was confirmed and he was able to sail (10 May 1890) for Africa, thus beginning what one of his biographers has called "the most traumatic journey of his life".

Letters written during the ocean voyage afford an insight into the state of mind of this 32-year-old bachelor whose career seemed to have lost any obvious direction. To his cousin by marriage and confidante Marguerite Poradowska, he wrote from the Canary Islands on 15 May:

One is sceptical of the future. For indeed, I ask myself, why should anyone have faith in it? And so why be sad? A little illusion, many dreams, a rare flash of happiness, then disillusion, a little anger and much pain, and then the end - peace! That is the programme, and we have to see this tragi-comedy through. We must resign ourselves to it.

The screw turns, taking me into the unknown....

Arriving in the Congo, he began to keep a diary (possibly the only one he ever kept), and to read its entries is to have a vivid sense of Conrad moving slowly, as he later made 
Marlow do, into the heart of what nineteenth-century Europe thought of as the "Dark Continent". By 1 September he had reached Stanley Falls, a thousand miles upstream: then, though suffering from fever and dysentery, he brought the Roi des Belges back to Kinshasa, an 18-day journey, after the captain had fallen ill. Back in England at the beginning of 1891, and still suffering from malaria, he revisited Brussels, just as Marlow does in the epilogue to the story.

In the passage from $A$ Personal Record already cited, Conrad describes his powerful short story "An Outpost of Progress" - written in 1896 and a kind of first sketch for Heart of Darkness - as "the lightest part of the loot I carried off from Central Africa, the main portion being of course Heart of Darkness". The passage continues:

Other men have found a lot of quite different things there and I have the comfortable conviction that what I took would not have been of much use to anybody else. And it must be said that it was but a very small amount of plunder. All of it could go into one's breast pocket when folded neatly.

Literary loot, literary plunder: Conrad's metaphors imply a sardonic comment both on his own creative methods and on the activities of those who had carried off from Africa more tangible forms of booty. For another dimension of the story public and historical rather than private and autobiographical - concerns the shameful record of European exploitation of the Congo. That this should so often have been accompanied by high-sounding professions of a missionary and civilizing purpose made a strong appeal to Conrad's keen sense of irony, and helped to determine the prevailing tone of the story.

The characteristic rhetoric was sounded in a speech made by King Leopold II of Belgium at a conference in Brussels in 1876, organized to consider how "to open to civilisation the only part of our globe where Christianity has not penetrated and to pierce the darkness which envelops the entire population". In this plausible cover-story for ruthless economic exploitation, what was to become Conrad's central symbol is already present. The International Association of the Congo was established, and at another conference, held in Berlin in 
1884, the Congo became Leopold's personal property. (This second conference had been summoned by Bismarck in response to growing competition among various European nations for the rich spoils offered by Africa - the "scramble for Africa".)

Consequently, as a historian of the Congo, Maurice N. Hennessy, has said, "Between 1885 and 1908 Leopold II was the supreme legislative and executive authority in the Congo Free State". He never visited the country, however, ruling it from Brussels through an Administrator General and, in the field, through agents. It was this arrangement that Leopold referred to in a speech made in the very year in which Conrad began to write Heart of Darkness, where he described the task of his agents as being "to continue the development of civilisation in the centre of Equatorial Africa, receiving their inspiration directly from Berlin and Brussels". In phrases that again seem to anticipate Conrad's story, he added that these agents, "placed face to face with primitive barbarism, grappling with sanguinary customs that date back thousands of years, ... . are obliged to reduce these gradually".

The story, however, refuses to foreground the historical and political elements, important though they were in its conception and motivation. For Conrad's ultimate purpose is to transform both public and private history into fable and metaphysical drama: not only to show the thinness of the veneer covering modern European civilization, and the emptiness of contemporary claims to inhabit an age of progress and enlightenment, but to suggest that these moral and ethical failings derive from a human nature that is itself deeply flawed. (Two later texts that owe much to Conrad's story draw attention to these aspects: T. S. Eliot's poem "The Hollow Men" (1925), which has a quotation from the story as its epigraph ("Mistah Kurtz - he dead"), takes up the theme of the spiritual hollowness of modern man, while William Golding's novel Lord of the Flies (1954) has on its last page the phrase "the darkness of man's heart" as a summing-up of that novel's own vision of the latent, and only just latent, human potentiality for evil.)

Thus the Brussels that Marlow visits at the beginning and end of his Congo journey is not so much a late nineteenthcentury European capital as a gateway to the underworld, 
and the African scenes through which Marlow travels are at least as much symbolic as actual landscapes and riverscapes. The framing of the main narrative by the peaceful evening scene on the Thames estuary, where a group of well-fed and presumably well-to-do middle-aged Englishmen listen to Marlow's yarn, has a deliberately distancing effect. And the use of Marlow as protagonist and narrator of the central narrative works to a similar effect. For Marlow, though he clearly has much in common with Conrad (their very names have the same number of letters and the same vowels), is not Conrad or even just a convenient mouthpiece for the author but a fictional character in his own right, with a fictional identity that extends beyond this particular tale.

In any case, though, to discuss Heart of Darkness in traditional terms of story and character is to risk misrepresenting its nature and the extent of its profound originality, for in many respects it needs to be read less like a nineteenthcentury work of fiction than like a modern poem. Symbols, allusions, verbal echoes and cross-currents make it closer to The Waste Land than to a novel by one of Conrad's contemporaries such as George Gissing and H. G. Wells. On the very first page, after a short opening paragraph that seems deliberately matter-of-fact and circumstantial ("The Nellie, a cruising yawl, swung to her anchor ..."), the language quickly becomes more poetic and suggestive: the Thames is "the beginning of an interminable waterway" that, as we understand with hindsight, will lead Marlow and the reader into the heart of Africa. Words like "dark", "gloom" and "brooding", which will make many subsequent appearances, establish a distinctive tone.

Then, with impressive economy, the pages that follow take us from the present - Victorian London is "the biggest, and the greatest, town on earth" - to the Elizabethan explorers and buccaneers, to the Roman colonists in Britain, to the Congo. This is not, however, a mere historical survey but an attempt to get at the truth behind the patriotic and sentimental versions of history that were current: "The conquest of the earth, which mostly means the taking it away from those who have a different complexion or slightly flatter noses than ourselves, is not a pretty thing when you look into it too much." 
This ironic view of historiography introduces one of the central concerns of the entire story: the moral significance of truth-telling and lying. Kurtz's rhetoric, like that of Leopold, is a smokescreen for real motives and real actions; as Marlow remarks at one point, even Kurtz's very name was a lie (it approximates to the German for "short", whereas he was a very tall man). At another point he observes:

You know I hate, detest, and can't bear a lie, not because I am straighter than the rest of us, but simply because it appals me. There is a taint of death, a flavour of mortality in lies - which is exactly what I hate and detest in the world - what I want to forget. It makes me miserable and sick, like biting something rotten would do.

Yet at the end of the story Marlow finds himself obliged to tell a lie, for the truth "would have been too dark - too dark altogether. ..".

Marlow's integrity involves a considerable degree of candour with regard to his own short-comings, and his maturity consists partly in a full recognition of the defects in his own nature. For him, as for Conrad, work is a form of salvation: engrossing toil fulfils for him the function of worship or prayer in a religious nature. Threatened with moral decay in the Congo, he is saved, as he half-jokingly says, by rivets, the trivial but indispensable and very solid objects needed to repair the badly damaged boat. But elsewhere he confesses:

No, I don't like work. I had rather laze about and think of all the fine things that can be done. I don't like work - no man does - but I like what is in the work - the chance to find yourself. Your own reality - for yourself, not for others - what no other man can ever know. They can only see the mere show, and never can tell what it really means.

There are figures in the story whose existence, as perceived by others and even by themselves, is "mere show", and Kurtz's dying cry may be a final recognition of this obstinate and cowardly refusal to confront the truth about oneself. What Marlow represents, and what for Conrad was of central moral importance, is self-discovery and self-knowledge.

Perhaps the most enlightening direct comment made by Marlow occurs at the very beginning of his narrative: 
to understand the effect of it on me you ought to know how I got out there, what I saw, how I went up that river to the place where I first met the poor chap. It was the farthest point of navigation and the culminating point of my experience. It seemed somehow to throw a kind of light on everything about me - and into my thoughts. It was sombre enough, too - and pitiful - not extraordinary in any way - not very clear either. No, not very clear. And yet it seemed to throw a kind of light.

In these few lines much of the meaning and method of the entire story is adumbrated. The journey is a spiritual as well as a physical odyssey and ordeal; its effect is profoundly educative, yet it throws only "a kind of light", and the contrastive element of darkness is engaged in a struggle with whatever power the light may possess. It is no accident, and it may possibly be read as evidence of an ultimate pessimism, that the final word of the entire text, even after the scene has shifted back from the Congo to the Thames, is not "light" but "darkness".

At first sight The Secret Agent seems to be a very different kind of work of fiction from Heart of Darkness. Disarmingly (but misleadingly) subtitled "A Simple Tale", its central concern appears to be with family relationships, and its pivotal incident is described by the Assistant Commissioner as "a domestic drama". Conrad has abandoned the male world of seafaring and its shared labours, dangers and values ("the bond of the sea") for an urban setting in which the most important relationship portrayed is a marriage, two of the main characters are women, and almost none of them are engaged in productive labour.

These differences, however, conceal some important similarities. Heart of Darkness, as already noted, begins in the vicinity of London, "the biggest, and the greatest, town on earth"; a couple of pages later, "the monstrous town" is evoked in language closely resembling that which is soon to be used of the Congo: "a brooding gloom in sunshine, a lurid glare under the stars". In The Secret Agent the largest and most highly developed city in the world is frequently depicted as a kind of jungle (a strategy to be used again, long 
afterwards and to brilliant effect, in Evelyn Waugh's $A$ Handful of Dust). Investigating the dark labyrinth of Soho, the Assistant Commissioner feels "as though he had been ambushed all alone in a jungle many thousands of miles away from departmental desks and official inkstands". Even the dignified premises of a government ministry have "something of a forest's deep gloom". And one of the terrorists describes "the present economic conditions" as "cannibalistic" - "They are nourishing their greed on the quivering flesh and the warm blood of the people". These last phrases fill the sensitive Stevie with horror, and by a subtle stroke Conrad echoes them in the account of Stevie's own remains as "what might have been an accumulation of raw material for a cannibal feast" - a vein of black comedy that seems to transport us back to the crew of the Congo steamer.

Verloc, like Kurtz, is a European figure ("All Europe contributed to the making of Kurtz"), a kind of representative compound of rootless modern Western man. Though he claims, in his conversation with Mr Vladimir, to be English, his name (Adolf Verloc) is clearly non-English and he has done his military service "in the French artillery". The grotesque and fanatical "Professor" also has something in common with Kurtz in his combination of egotism, ruthlessness and eloquence, and actually echoes the earlier figure when he declares "Exterminate, exterminate! That is the only way of progress".

In Heart of Darkness Marlow, travelling up the Congo, seems to be journeying not only through space into the heart of the Dark Continent (and metaphorically into a "heart of darkness") but back through time into a landscape peopled by prehistoric creatures and fantastic forms of vegetation, all engaged in a Darwinian struggle for survival ("Going up that river was like travelling back to the earliest beginnings of the world ..."). Comparably, the modern city is a place in which the struggle for survival continues: Winnie has sacrificed her happiness, as her mother later sacrifices hers, in a vain attempt to save Stevie from the cruelty of an indifferent world, while Verloc sacrifices Stevie to safeguard (though again the attempt is vain) his own precarious future. Just beneath the surface of the life of the great city, a monument to modern technological and organizational achievements, is a 
primitive world of impulses and actions, and when Winnie commits murder her hand is driven by "all the inheritance of her immemorial and obscure descent, the simple ferocity of the age of caverns, and the unbalanced nervous fury of the age of bar-rooms" (italics added).

The Secret Agent, it is true, does not share the potent personal origins of the earlier story. As the long "Author's Note" makes clear, and as Norman Sherry had demonstrated in detail in his valuable study Conrad's Western World, the genesis of the novel lay in public events rather than private experience. At the same time, however, both texts illustrate in their different ways a general truth concerning Conrad's creative processes - that, as Professor Sherry puts it, his "imagination required always a firm basis of fact". The idea of blowing up the Greenwich Observatory as an anarchist act of terrorism must have appealed to Conrad on account of its bizarrely symbolic nature. For the meridian line at Greenwich is itself a kind of symbol and can no more be destroyed by violent action than one can destroy the Equator or the North Pole. What is in the event destroyed is Stevie, the mentally handicapped brother to whom Winnie has devoted her life, and the two worlds of the novel, the domestic and the political, are thus brought together in an inextricable relationship.

The irony that is intermittent in Heart of Darkness is pervasive in The Secret Agent and begins on the title-page. The title seems to promise a thriller, an old-fashioned and undemanding tale of adventure, perhaps in the manner of Conrad's slightly younger contemporary John Buchan, but what the reader finds is something very different. As for the subtitle, the novel is very far from being "A Simple Tale", in either content or form. The narrative method, involving the socalled "time-shift", defies ordinary rules of suspenseful storytelling by disclosing the outcome at an early stage ("There's a man blown up in Greenwich Park this morning"). The irony that permeates not only character and situation but the very language of the novel - language being the target as well as the vehicle of Conrad's irony - means that nothing can be taken at face value and conventional judgments are constantly being exposed as false.

There is, for instance, a comic and ironic paradox at the heart of Verloc's very identity. He is a professional anarchist 
but also a married man and small shopkeeper who regards himself as a model husband, a respectable member of petit bourgeois society, and a loyal servant to the foreign Embassy which is his employer in his "secret" second profession as spy and informer. Mr Vladimir, the arrogant intellectual who violently rocks the boat of Verloc's complacency and security, and is the ultimate cause of the novel's central action, at once detects the absurdity of Verloc's situation as a married anarchist, the very notion of which is a comic oxymoron.

In the long scene that culminates in Verloc's murder, the ironies multiply. With the best intentions in the world - but then, in the world of this novel the best intentions count for nothing - Winnie Verloc has been the unwitting agent of her brother's death by forcing him upon the attention of her husband and encouraging their excursions ("Might have been father and son"); equally unwittingly, she becomes the agent of her husband's implication in the boy's death through the label sewn into Stevie's clothing. When husband and wife come together, Verloc is totally unaware of the nature of his wife's feelings, as indeed he has been throughout their entire relationship, and the language used, at once comically inflated and absurdly formal, reflects his moral and imaginative failure. "Thoroughly domesticated", he feels a "conjugal optimism" and "marital solicitude"; "magnanimous in his conduct", he shows "true greatness of soul" and is "resigned in a truly marital spirit".

The formality of these phrases constitutes an ironic commentary on accepted attitudes to the marital relationship and on the language through which such judgments are made and expressed, and it is a mode that has been established very early in the book. On the first page, the coy euphemism "nether garments" (for "trousers") appears in an account of the shamefaced customers of Verloc's shop, and at the beginning of Chapter 2 the unattractive figure of Verloc is described in mock-heroic vein as exhaling "the charm of almost dewy freshness".

From beginning to end, that is, the reader is invited to question stock judgments and stock phrases, and - on a deeper level - to re-examine accepted notions of "respectability" and social acceptability. Under the guise of a story of a "secret agent" Conrad offers an extended investigation into the 
sordid and the banal, but his achievement is to make high drama and serious moral enquiry out of these unpromising materials: it is thus entirely fitting that, at the end of Chapter 11, Verloc should be killed with a "domestic carving knife" (an item that, like the fatal marking ink, has been earlier alluded to in more innocent contexts), and that the final image of this intensely powerful chapter should be the comic one of the dead man's hat, lying on the floor and rocking slightly on its crown in the draught created by the woman's flight.

In some of its most effective scenes, the novel also makes use of the specialized kind of irony known as dramatic irony and found, for instance, in Greek tragic drama: the kind of ironic situation, that is, in which the readers or audience, knowing the outcome of what is taking place, witness the characters moving unknowingly towards their doom. At the beginning of Chapter 9 Winnie, as already noted, encourages her husband to take an interest in Stevie: "You could do anything with that boy, Adolf"; "I wish you would take that boy out with you, Adolf". And to his objection that Stevie might get lost, she offers vague reassurance without disclosing that she has sewn Stevie's name into his clothes. Here again the banal exchanges between husband and wife are fraught with high drama and tragic consequences - though neither of them quite realizes the implications of what is being said, their mutual incomprehension reflecting the limitations of their marital relationship.

There is dramatic irony too in the fine scene in which Winnie's mother goes off to a life of self-inflicted loneliness in an almshouse in the aching hope that her self-sacrifice will ensure Stevie's welfare as an inhabitant of Mr Verloc's household. It is, of course, an act that produces a result precisely opposite to that which was intended, and the pessimistic message seems to be that such acts of love and nobility count for nothing in the face of the contingencies of a harsh universe and the conditions of an inhuman society.

In one important respect the world of The Secret Agent is radically different from that of Heart of Darkness - or of The Shadow-Line, to be considered in a moment. Whereas the journey motif of both of the latter stories, and their nature as Bildungsromanen or novels of growth and education, give them a forward-thrusting dynamic, the land-locked world of 
The Secret Agent is enclosed and claustrophobic, aptly symbolized by the circles that are drawn obsessively by Stevie. The majority of its scenes take place indoors, and the rooms occupied by its characters are often poky, overcrowded and ill-ventilated. Even the streets are murky and greasy with rain and fog. And the inner world of many of the characters resembles this outer world in being circumscribed and confined. When Winnie is in flight,

The vast world created for the glory of man was only a vast blank to Mrs. Verloc. ... She was alone in London: and the whole town of marvels and mud, with its maze of streets and its mass of lights, was sunk in a hopeless night, rested at the bottom of a black abyss ...

Such evocations of the city as a crowded "maze" in which it is possible to be more lonely and isolated than in a desert inevitably bring to mind Dickens, whose novels helped to create modern concepts of the city. Conrad had read Dickens in childhood and the influence is widespread in his work. In this novel, as F. R. Leavis pointed out in The Great Tradition, the Dickensian influence is particularly potent - in, for instance, the nightmarish and surrealistic cab drive that conveys the old lady to the almshouse. Hugh Walpole, writing in 1929, considered this scene "the most beautiful, touching and moving thing in the whole of Conrad" and "one of the great things in English literature", and as early as 1907 Conrad's friend Edward Garnett had identified this character in a review (The Nation, 28 September) as "the real heroine of the story" - a verdict endorsed by Conrad himself, who wrote to Garnett on 1 October: "You've got a fiendishly penetrating eye for one's most secret intentions. She is the heroine."

Elsewhere, in the concluding passage of the novel, the mechanical piano that accompanies Ossipon's reading of the newspaper account of Winnie's death is a touch of Dickensian grotesque and animistic fantasy, as is, earlier, Winnie's horrified mental vision of fragments of her beloved brother descending in dream-like fashion from the air ("after a rainlike fall of mangled limbs the decapitated head of Stevie lingered suspended alone, and fading out slowly like the last star of a pyrotechnic display"). 
Of all Dickens's novels it is perhaps Bleak House that is most potently present in Conrad's text, and the famous opening description of London in a November fog seems to be echoed - not just in mood but in specific detail - in a passage near the end of Chapter 7:

His descent into the street was like the descent into a slimy aquarium from which the water had been run off. A murky, gloomy dampness enveloped him. The walls of the houses were wet, the mud of the roadway glistened with an effect of phosphorescence, and when he emerged into the Strand out of a narrow street by the side of Charing Cross Station the genius of the locality assimilated him.

The phrase "the genius of the locality" - an Anglicizing of the Latin "genius loci" - is typical of a Conradian mannerism in this novel whereby a world of classical learning and implied upper-class education is invoked in a banal or sordid context. (Mr Vladimir, quoting Latin at Mr Verloc, has been told that the latter is ignorant of the language.) Later $\mathrm{Mr}$ Verloc is compared, with comic incongruity, to a peripatetic philosopher as he strolls through the London streets with Stevie at his side, the allusively implied world of high culture and privilege emphasizing by contrast the physical and moral squalor of the represented world.

The Secret Agent was not on the whole well received by contemporary reviewers. One, for instance, declared that "It would appear that Mr Conrad had set himself the impossible task of trying to make dulness interesting" (Country Life, 21 September 1907). By 6 January 1908 Conrad felt obliged to confess, in a letter to John Galsworthy, that his novel "may be pronounced by now an honourable failure. It brought me neither love nor promise of literary success". Forty years later, and a generation after Conrad's death, Leavis insisted that it was one of the author's greatest achievements, and this view has been endorsed by many subsequent critics.

It can now be recognized that, as Conrad himself made clear to friends, it was an experiment of a bold kind. To R. B. Cunninghame Graham he wrote on 7 October 1907 that it "had some importance for me as a new departure in genre and as a sustained effort in ironical treatment of a melodramatic subject". The telling and wholly justified word here is 
"sustained", and one of the most impressive features of this great novel is the unflagging control and consistency with which the "ironical treatment" is maintained. Few novels, even those enjoying classic status, possess such unity and coherence and pursue their objectives with such intense concentration and so little deviation.

Like Heart of Darkness, The Shadow-Line is a story of initiation and rites of passage, of the transition from innocence to experience, and like that earlier story it draws heavily on the writer's personal past. Conrad described it to at least two of his friends as "exact autobiography", and to a third - more plausibly - as "a sort of autobiography". Since it belongs to the final phase of his creative career and the last decade of his life, it involves an act of retrospection extending over almost thirty years.

On 22 August 1887 Conrad, then in Singapore, had joined the crew of the steamer Vidar under Captain James Craig and had made several trips to Borneo. Little more than four months later, however, he had quitted the Vidar and, after hanging about at the Sailors' Home in Singapore for a couple of weeks, had gone to Bangkok to take over as captain of the Otago, whose captain had died at sea on the voyage from Adelaide. It was his first command, and long afterwards was to furnish material for two masterpieces, "The Secret Sharer" (written in 1909 and included in the volume 'Twixt Land and Sea) as well as The Shadow-Line.

Conrad was to spend some fourteen months on the Otago. Leaving Bangkok on 9 February, the ship arrived in Singapore on 2 March, the Singapore Free Press reporting that "the Captain wished to get a further supply of medicine before he proceeded on his journey", since "several of the crew are suffering from fever". From Singapore his route then took him to Sydney; to Melbourne and back to Sydney; to Mauritius; back to Melbourne, and on to Minlaton in South Australia; and finally to Port Adelaide. There his employers asked him to take the ship back to Mauritius, an invitation which he declined, resigning his command and returning to England as a passenger on the steamship Nurnberg. He had had his share of trials and dangers during the period he had spent 
with the Otago: not only a sick crew but a gale between Singapore and Sydney and a passage through the notoriously hazardous Torres Strait en route for Mauritius.

Inevitably the story shortens, simplifies and focuses this material: it is, after all, only "a sort of autobiography", and the necessary points can be made by restricting the fictional narrative to the first stage of Conrad's time with the Otago. But many of the components of the story, including the names of some of the characters, are taken from life: the boredom of the period spent in the Sailors' Home, the unexpectedness with which the offer of a ship is made, the setting in the Gulf of Siam, the sick crew. At the heart of the story, however, is the young captain's process of self-discovery: the relatively short time spent on the ship is a turning-point in his existence at which he exchanges youth and the illusions of inexperience for maturity and an enhanced and deepened sense of reality. Conrad had just turned thirty when he took over the command of the Otago - a point in their lives at which many people have a sense of crossing a frontier - and there is no reason to suppose that the inner life of the story's protagonist was any less true to the remembered past than the outward circumstances.

Some critics have been troubled by the long opening section ashore, and have felt that this unduly delays, with some loss of narrative momentum, the real business of the story, which begins with the young man taking up his command. The justification must be that the initial depiction of life ashore, with its shiftlessness, its pretensions and its intriguing and deceptions, stands in necessary contrast to life at sea. In addition, the young man's unawareness of the machinations that are afoot in connection with the appointment that is to be made serves to stress his ignorance of the world.

Life at sea, however, offers a challenge that not all are prepared to accept, as Captain Ellis tells the narrator:

He interrupted me. "Why! Hang it! You are the right man for that job if there had been twenty others after it. But no fear of that. They are all afraid to catch hold. That's what's the matter."

He was very irritated. I said innocently: "Are they, sir? I wonder why?" 
"Why!" he fumed. "Afraid of the sails. Afraid of a white crew. Too much trouble. Too much work. Too long out here. Easy life and deckchairs more their mark."

A page or two earlier, even the imposing figure of Captain Ellis himself has been ironically presented (the irony belonging to the older narrator rather than the young observer) - for even he, despite his title, is now a landsman sitting in an office:

He was the supreme authority, the Marine Superintendent, the Harbour-Master - a very great person in the eyes of every single quilldriver in the room. But that was nothing to the opinion he had of his own greatness.

Captain Ellis looked upon himself as a sort of divine (pagan) emanation, the deputy-Neptune for the circumambient seas. If he did not actually rule the waves, he pretended to rule the fate of the mortals whose lives were cast upon the waters.

The contemptuous term "quill-driver" and the mock-heroic "deputy-Neptune for the circumambient seas", like the ironic allusion ("Britannia rules the waves"), enforce the private as against the public judgment of this man who is, after all, little more than a manager or bureaucrat.

In contrast, the ship whose command he is to assume represents for the young man a challenge to all that is deepest in his nature and his character, and the point, a little more than one-third of the way through the story, when he sees it for the first time has strongly emotional and even erotic overtones. The ship will be a test and a trial but is also an object of love and devotion. As he draws near he recognizes that "the time was approaching for me to behold my command and to prove my worth in the ultimate test of my profession", and that his life has suddenly assumed a purpose:

Yes, there she was. Her hull, her rigging filled my eye with a great content. That feeling of life-emptiness which had made me so restless for the last few months lost its bitter plausibility, its evil influence, dissolved in a flow of joyous emotion.

With hindsight that simple rapture can be identified as a kind of innocence or naivety, and it will not be long before he will 
curse his fate in linking him to the vessel; but the passionate reaction, akin to the feeling of a lover, is an important stage in the narrator's emotional and spiritual development.

The ship itself - "herself" for Conrad - is humanized and eroticized at this early stage:

At the first glance I saw that she was a high-class vessel, a harmonious creature in the lines of her fine body, in the proportioned tallness of her spars....

I knew that, like some rare women, she was one of those creatures whose mere existence is enough to awaken an unselfish delight. One feels that it is good to be in the world in which she has her being.

When they started lowering [the cargo into the hold] the surge of the tackle sent a quiver through her from water-line to the trucks up the fine nerves of her rigging, as though she had shuddered at the weight. ...

I received the feeling of deep physical satisfaction....

In all parts of the world washed by navigable waters our relation to each other would be the same - and more intimate than there are words to express in the language.

But if this has many of the appearances of a love affair, even a kind of marriage, it is one that will suffer setbacks and discord.

At first, however, the young captain experiences an exhilarating sense of "possession" that is again expressed in romantic and even sexual terms:

A ship! My ship! She was mine, more absolutely mine for possession and care than anything in the world; an object of responsibility and devotion. She was there waiting for me, spellbound, unable to move, to live, to get out into the world (till I came), like an enchanted princess.

That last phrase curiously echoes Heart of Darkness, where Marlow observes that "The approach to this Kurtz grubbing for ivory in the wretched bush was beset by as many dangers as though he had been an enchanted princess sleeping in a fabulous castle."

A few lines earlier than the sentence just quoted, Marlow has referred to "the dream-sensation that pervaded all my days at that time", and there is something of the "fabulous" and dream-like, even the nightmarish and supernatural, to be 
found in the later story. The voyage that has been begun in such high spirits soon seems to be the victim of a malevolent fate acting through the dead captain. When the ship is becalmed, the narrator exclaims that "Only purposeful malevolence could account for it", and later he describes himself in his journal as having been "decoyed into this awful, this death-haunted command ...". Elsewhere he comments that their state is "like being bewitched", and that "mysterious malefices" and "the evil powers of calms and pestilence" seemed to be working against "the first passage of my first command". It has often been pointed out that the narrative resembles in several respects that of Coleridge's The Rime of the Ancient Mariner, another story of a voyage in tropic regions that involves becalming, suffering and death, and ultimately leads to the moral education of the protagonist.

He does, however, pass the test or rite of passage and survive the ordeal, saved by a devotion to his calling that has given an indispensable strength to his character. Early in the story this devotion has been the occasion for one of the most eloquent passages (at the same time entirely free from rhetorical inflation or portentousness) to be found anywhere in Conrad's writings: when he learns that he has secured his first command,

A sudden passion of anxious impatience rushed through my veins and gave me such a sense of the intensity of existence as I have never felt before or since. I discovered how much of a seaman I was, in heart, in mind, and, as it were, physically - a man exclusively of sea and ships; the sea the only world that counted, and the ships the test of manliness, of temperament, of courage and fidelity - and of love.

The "test" referred to here is the theme of the ensuing narrative, and in its closing pages all that has happened is summed up as "that episode which had been maturing and tempering my character - though I did not know it".

Ashore once more, the young captain again meets Captain Giles: 
"You must feel jolly well tired by this time."

"No," I said. "Not tired. But I'll tell you, Captain Giles, how I feel. I feel old. And I must be. All of you on shore look to me just a lot of skittish youngsters that have never known a care in the world."

He didn't smile. He looked insufferably exemplary. He declared:

"That will pass. But you do look older - it's a fact."

Learning that living in the world brings "care" has involved crossing the "shadow-line" separating youth from maturity, innocence from experience: as the narrator tells Giles, "Well, I am no longer a youngster."

It is curious to reflect that The Shadow-Line originally appeared before the reading public in seven monthly instalments, for the tale has a unity and concentration that demand it be read with the minimum of interruption or distraction. In volume form it was a commercial and critical success, selling a first edition of 5000 copies within a few days and receiving accolades from many reviewers. The Spectator described it as "a great and never-to-be-forgotten book", while the Sphere stated that Conrad had become "not only one of the favourite novelists of the elect but one of the favourite novelists of the many". The early failures, disappointments and despair were behind him, but it is touching to think that in this late masterpiece, whose quality has been endorsed by many more recent critics, its author should have returned to his youth and his own first command. Conrad is often misleading (whether innocently or reprehensibly) in his statements about the relationship of his work to his early experience, but there cannot be much doubt that the emotions of the first-person narrator in The Shadow-Line had long ago been felt on its author's pulses. 